\title{
Density Functional Theory (DFT) and DRIFTS Investigations of the Formation and Adsorption of Enolic Species on the $\mathrm{Ag} / \mathrm{Al}_{2} \mathrm{O}_{3}$ Surface
}

\author{
Hongwei Gao, Hong He,* Yunbo Yu, and Qingcai Feng \\ Research Center for Eco-Environmental Sciences, Chinese Academy of Sciences, Beijing, 100085, China
}

Received: February 24, 2005; In Final Form: May 10, 2005

\begin{abstract}
Molecular structure and vibrational frequencies of the novel surface enolic species intermediate on $\mathrm{Ag} / \mathrm{Al}_{2} \mathrm{O}_{3}$ have been investigated by means of density functional theory (DFT) calculations and in situ infrared spectroscopy. The geometrical structures and vibrational frequencies were obtained at the B3P86 levels of DFT and compared with the corresponding experimental values. Theoretical calculations show that the calculated IR spectra are in good agreement with the experimental spectroscopic results. In addition, the adsorption energy of enolic species on the $\mathrm{Ag} / \mathrm{Al}_{2} \mathrm{O}_{3}$ catalyst surface was also evaluated. The reaction mechanism from $\mathrm{C}_{2} \mathrm{H}_{5} \mathrm{OH}$ to enolic species on $\mathrm{Ag} / \mathrm{Al}_{2} \mathrm{O}_{3}$ catalyst was proposed.
\end{abstract}

\section{Introduction}

The alumina supported silver catalyst $\left(\mathrm{Ag} / \mathrm{Al}_{2} \mathrm{O}_{3}\right)$ has been studied as a promising catalyst due to its high activity for the selective catalytic reduction ( $\mathrm{SCR}$ ) of $\mathrm{NO}_{x}$ by hydrocarbons in the presence of excess oxygen. ${ }^{1-3}$ In particular, $\mathrm{C}_{2} \mathrm{H}_{5} \mathrm{OH}$ is extremely effective for the SCR of $\mathrm{NO}_{x}$ over $\mathrm{Ag} / \mathrm{Al}_{2} \mathrm{O}_{3}{ }^{3}$ On the basis of these studies, a possible mechanism for the SCR of $\mathrm{NO}_{x}$ by $\mathrm{C}_{2} \mathrm{H}_{5} \mathrm{OH}$ over $\mathrm{Ag} / \mathrm{Al}_{2} \mathrm{O}_{3}$ was considered as similar to that of $\mathrm{C}_{3} \mathrm{H}_{6}$, approximately, $\mathrm{NO}+\mathrm{O}_{2}+\mathrm{C}_{2} \mathrm{H}_{5} \mathrm{OH} \rightarrow \mathrm{NO}_{x}$ (nitrate in particular) $+\mathrm{C}_{x} \mathrm{H}_{y} \mathrm{O}_{z}$ (acetate in particular) $\rightarrow \mathrm{R}-\mathrm{NO}_{2}$ $+\mathrm{R}-\mathrm{ONO} \rightarrow-\mathrm{NCO}+-\mathrm{CN}+\mathrm{NO}+\mathrm{O}_{2} \rightarrow \mathrm{N}_{2} \cdot{ }^{4,5}$ However, this mechanism does not sufficiently explain why $\mathrm{C}_{2} \mathrm{H}_{5} \mathrm{OH}$ has a higher efficiency for the SCR of $\mathrm{NO}_{x}$ over $\mathrm{Ag} / \mathrm{Al}_{2} \mathrm{O}_{3}$ than $\mathrm{C}_{3} \mathrm{H}_{6}{ }^{6}$

Recently, we found a novel surface species on the $\mathrm{Ag} / \mathrm{Al}_{2} \mathrm{O}_{3}$ surface during the partial oxidation of $\mathrm{C}_{2} \mathrm{H}_{5} \mathrm{OH}$, which was assigned to an enolic species $\left(\mathrm{CH}_{2}=\mathrm{CH}-\mathrm{O}^{-}\right)$based on the feature of 1633,1416 , and $1336 \mathrm{~cm}^{-1}$ shown in the in situ FTIR. ${ }^{3}$ The enolic species has been suggested as an important reaction intermediate that relates to the higher efficiency for the SCR of $\mathrm{NO}_{x}$ with $\mathrm{C}_{2} \mathrm{H}_{5} \mathrm{OH}$ as a reductant. ${ }^{6}$ One evidence is that the IR spectra of syn-vinyl alcohol $\left(\mathrm{CH}_{2}=\mathrm{CHOH}\right)$ in the gas phase show a strong peak between 1644 and $1648 \mathrm{~cm}^{-1}$, which is accompanied by two peaks at 1409-1412 and 1300$1326 \mathrm{~cm}^{-1} \cdot{ }^{7-10}$ However, no IR data of an enolic species have been reported on the adsorbed status. Therefore, we have no experimental evidence to directly support our assignment of surface enolic species.

Auxiliary computer simulation of IR spectra with density functional theory (DFT) quantum mechanical methods affords highly powerful and reliable tools for analytical chemistry by means of in situ Diffuse Reflectance Infrared Fourier Transform Spectroscopy (DRIFTS). Due to the use of IR simulations, impressive advances have been achieved in separation and unambiguous identification of complex mixtures of organic compounds. The most efficient is especially for the analysis of unknown compounds. DFT calculations are increasingly being applied to predict the interactions of adsorbates with catalytic

* Corresponding author. Phone: +86-10-62849123. Fax: +86-1062923563. E-mail: honghe@mail.rcees.ac.cn.

10.1021/jp050955+ CCC: \$30.25 sites. ${ }^{11}$ Such DFT methods provided accurate geometries, and reasonable energetics for molecules containing transition metals $^{12-15}$ are sufficient to describe the active sites in comparison of the predictions with experimental data.

The objective of this work is to study the adsorbed enolic species on the $\mathrm{Ag} / \mathrm{Al}_{2} \mathrm{O}_{3}$ catalyst with experimental and theoretical methods. This study aims to utilize in situ FTIR spectroscopies and simulant ones toward the understanding of the formation of these active sites on the $\mathrm{Ag} / \mathrm{Al}_{2} \mathrm{O}_{3}$ catalyst and their involvement in the reaction mechanism of the SCR of $\mathrm{NO}_{x}$. The fundamental understanding of the reaction mechanism of the SCR of $\mathrm{NO}_{x}$ is believed to be essential for the development of the catalyst and improvement for potential application.

\section{Computational Section}

Minimum energy structure and normal mode calculations were performed for ten calculated models with the Gaussian98 program. The properties of the calculated models were determined through the application of density functional theory (DFT), using the B3P86 gradient corrected function (Becke's 3 -parameter function with the nonlocal correlation provided by the Perdew 86 expression). The LANL2DZ effective core potential basis set was used for all of the calculations. The LANL2DZ basis replaced the 1 s through $2 p$ electrons of the heavy atoms with a potential field for a considerable computational savings. A double- $\zeta$ quality Dunning basis was used for the light atoms and the remaining heavy atom electrons. Stability calculations confirmed the ground-state configuration of all the wave functions. The calculated vibration frequencies and infrared intensity of the vibrational normal modes with Gaussian98 are picked up by the Hyperchem Version 6.0 package.

\section{Experimental Section}

The $\mathrm{Ag} / \mathrm{Al}_{2} \mathrm{O}_{3}$ catalyst (Ag loading is $5.0 \mathrm{wt} \%$ ) was prepared by an impregnation of $\gamma-\mathrm{Al}_{2} \mathrm{O}_{3}$ powder $\left(200 \mathrm{~m}^{2} / \mathrm{g}\right)$ with an appropriate amount of silver nitrate aqueous solution. The sample was dried at $393 \mathrm{~K}$ for $3 \mathrm{~h}$ and calcined at $873 \mathrm{~K}$ for 3 $\mathrm{h}$ in air.

In situ Diffuse Reflectance Infrared Fourier Transform Spectroscopy (DRIFTS) spectra were recorded with a Nexus 


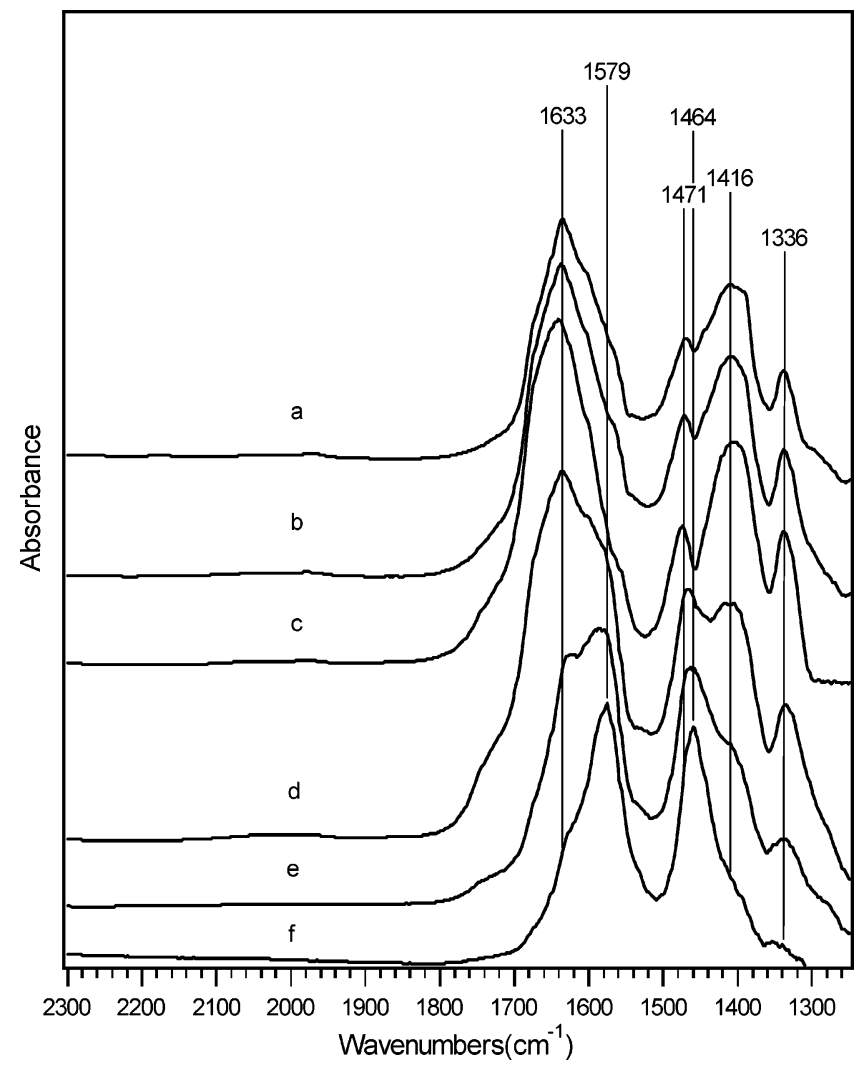

Figure 1. The experimental in situ DRIFTS spectra of adsorbed species in steady states on $\mathrm{Ag} / \mathrm{Al}_{2} \mathrm{O}_{3}$ in a flow of $\mathrm{C}_{2} \mathrm{H}_{5} \mathrm{OH}+\mathrm{O}_{2}$ at (a) 473 , (b) 523, (c) 573, (d) 673, (e) 773, and (f) $873 \mathrm{~K}$. Conditions: $\mathrm{C}_{2} \mathrm{H}_{5} \mathrm{OH}$ $1565 \mathrm{ppm}, \mathrm{O}_{2} 10 \%$.

670 (Thermo Nicolet) FT-IR, equipped with an in situ diffuse reflection chamber and a high-sensitivity MCT detector. The $\mathrm{Ag} / \mathrm{Al}_{2} \mathrm{O}_{3}$ catalyst for the in situ DRIFTS studies was finely ground and placed into a ceramic crucible in the in situ chamber. Mass flow controllers and a sample temperature controller were used to simulate the real reaction conditions, such as mixture of gases, pressure, and sample temperature. Prior to recording each DRIFTS spectrum, the sample was heated in situ in $10 \%$ $\mathrm{O}_{2} / \mathrm{N}_{2}$ flow at $873 \mathrm{~K}$ for $1 \mathrm{~h}$, then cooled to the desired temperature befor taking a reference spectrum. All gas mixtures were fed at a flow rate of $100 \mathrm{~mL} / \mathrm{min}$. All spectra were measured with a resolution of $4 \mathrm{~cm}^{-1}$ and with an accumulation of 100 scans.

\section{Results and Discussion}

4.1. Experimental Results. Figure 1 shows the in situ DRIFTS of $\mathrm{Ag} / \mathrm{Al}_{2} \mathrm{O}_{3}$ in a flow of $\mathrm{C}_{2} \mathrm{H}_{5} \mathrm{OH}(1565 \mathrm{ppm})+\mathrm{O}_{2}$ $(10 \%)$ at a temperature range of $473-873 \mathrm{~K}$ in steady states. Exposure of this catalyst to the fed gas at $473 \mathrm{~K}$ resulted in the appearance of five peaks $(1633,1579,1471-1464,1416$, and $\left.1336 \mathrm{~cm}^{-1}\right)$. Peaks at 1579 and $1471-1464 \mathrm{~cm}^{-1}$ were assigned to $v_{\text {as }}(\mathrm{OCO})$ and $v_{\mathrm{s}}(\mathrm{OCO})$ of acetate, respectively. ${ }^{16-22}$ According to our earlier studies, ${ }^{3}$ peaks at 1633,1416 , and $1336 \mathrm{~cm}^{-1}$ were assigned to asymmetric stretching vibration, symmetric stretching vibration, and $\mathrm{C}-\mathrm{H}$ deformation vibration modes of an adsorbed enolic species, respectively. Apparently, the enolic species is predominant during the oxidation of $\mathrm{C}_{2} \mathrm{H}_{5} \mathrm{OH}$ on the $\mathrm{Ag} / \mathrm{Al}_{2} \mathrm{O}_{3}$ surface within a low-temperature range of 473-673 $\mathrm{K}$. However, the surface acetate species becomes dominant at a high-temperature range of $773-873 \mathrm{~K}$.

4.2. Computational Results. 4.2.1. Calculation Models. In our earlier study, ${ }^{3}$ we proposed that the peak at $1633 \mathrm{~cm}^{-1}$ would be associated with the frequency of double bond stretching vibration, such as $v(\mathrm{C}=\mathrm{C})$ and $v(\mathrm{C}=\mathrm{O})$. In general, however, stretching vibration frequencies of isolated $\mathrm{C}=\mathrm{C}$ and $\mathrm{C}=\mathrm{O}$ should be higher than $1633 \mathrm{~cm}^{-1}$. It should be noted that the IR spectra of gas-phase phenol and methoxy ethene give peaks between 1600 and $1650 \mathrm{~cm}^{-1},{ }^{7}$ as do the IR spectra of adsorbed catechol on a $\mathrm{TiO}_{2}$ colloid and chemisorbed acetoneoxygen mixtures on nickel oxide. ${ }^{5,24}$ Their common characteristic is an enolic structure. In this study, we conjectured that an enolic anion $\mathrm{R}_{2} \mathrm{C}=\mathrm{CH}-\mathrm{O}^{-}$was formed during this process. The conjugation of the $\mathrm{R}_{2} \mathrm{C}=\mathrm{CH}-\mathrm{O}^{-}$group may induce the vibrational mode of $\mathrm{C}-\mathrm{C}-\mathrm{O}$ to shift to a frequency lower than $v(\mathrm{C}=\mathrm{C})$ and $v(\mathrm{C}=\mathrm{O}){ }^{3,5,7,23}$ Moreover, the peaks of $\mathrm{CH}_{3} \mathrm{CHO}$ $(\mathrm{m} / \mathrm{z}, 29), \mathrm{CH}_{3} \mathrm{CH}=\mathrm{CH}^{+}(\mathrm{m} / \mathrm{z} 41), \mathrm{CH}_{2}=\mathrm{CHCHO}(\mathrm{m} / \mathrm{z}, 56)$, and $\mathrm{CH}_{2}=\mathrm{CH}-\mathrm{CH}=\mathrm{CH}-\mathrm{OH}(\mathrm{m} / \mathrm{z}, 70)$ fractions originating from the thermal decomposition of the enolic species were observed in TPD spectra. ${ }^{24}$ Therefore, we designed the calculated models containing two, three, and four carbon backbones (see Figure 2) to study the mechanism of enolic species adsorption on the $\mathrm{Ag} / \mathrm{Al}_{2} \mathrm{O}_{3}$ cluster.

4.2.2. Mechanism for the Formation of Absorbed Enolic Species over $\mathrm{Ag} / \mathrm{Al}_{2} \mathrm{O}_{3}$ Catalyst. During the partial oxidation of $\mathrm{C}_{2} \mathrm{H}_{5} \mathrm{OH}$ over $\mathrm{Ag} / \mathrm{Al}_{2} \mathrm{O}_{3}$ at $473-873 \mathrm{~K}$, peaks at 1633,1416 , and $1336 \mathrm{~cm}^{-1}$ were observed, moreover, these peaks predominate (shown in Figure 1), indicating that enolic species are the main surface species. In TPD-MS, ${ }^{24}$ the peaks of $\mathrm{CH}_{3} \mathrm{CHO}$ $(\mathrm{m} / \mathrm{z}, 29)$ and $\mathrm{CH}_{2}=\mathrm{CH}-\mathrm{CH}=\mathrm{CH}-\mathrm{OH}(\mathrm{m} / z, 70)$ fraction are the main peaks. On the basis of DRIFTS (Figure 1) and TPD$\mathrm{MS},{ }^{24}$ we proposed the mechanism for the formation of absorbed enolic species $\left(\mathrm{CH}_{2}=\mathrm{CHO}^{-}\right)-\mathrm{M}^{+},\left(\mathrm{CH}_{2}=\mathrm{CHCH}_{2}-\mathrm{O}^{-}\right)-\mathrm{M}^{+}$, and $\left(\mathrm{CH}_{2}=\mathrm{CH}-\mathrm{CH}=\mathrm{CH}-\mathrm{O}^{-}\right)-\mathrm{M}^{+}$over the $\mathrm{Ag} / \mathrm{Al}_{2} \mathrm{O}_{3}$ catalyst as follows:

$$
\begin{aligned}
& \mathrm{C}_{2} \mathrm{H}_{5} \mathrm{OH} \stackrel{\text { oxidation }}{\underset{\mathrm{Ag} / \mathrm{Al}_{2} \mathrm{O}_{3}}{\rightleftharpoons}} \mathrm{CH}_{3} \mathrm{CHO} \stackrel{\text { isomerization }}{\rightleftharpoons} \\
& \mathrm{CH}_{2}=\mathrm{CHOH} \stackrel{-\mathrm{H}^{+}}{\longrightarrow} \mathrm{H}_{2} \mathrm{C} \\
& \mathrm{M}=\mathrm{Al}, \mathrm{Ag}
\end{aligned}
$$
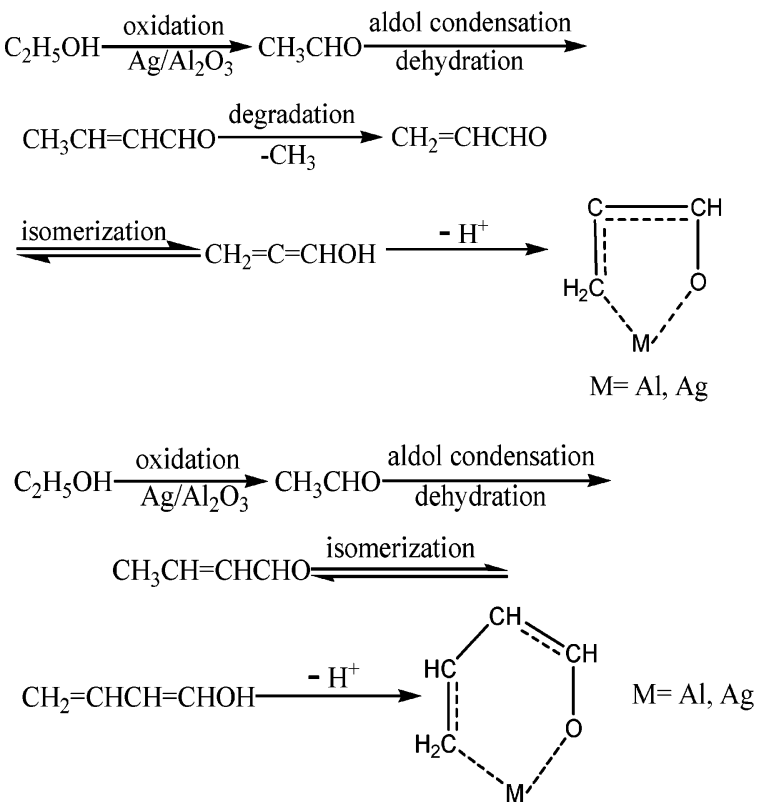

For reaction $1, \mathrm{C}_{2} \mathrm{H}_{5} \mathrm{OH}$ is first catalytically oxidized to $\mathrm{CH}_{3}-$ $\mathrm{CHO}$, then isomerizes and dehydrogenates to yield $\left(\mathrm{CH}_{2}=\mathrm{CH}-\right.$ 
<smiles>C1=C[GeH2]O1</smiles>

A<smiles>C1=C[AlH]O1</smiles>

B<smiles>C1=CO[Al]O1</smiles>

$\mathrm{C}$<smiles>[C]1OC=CCO1</smiles>

$\mathrm{D}$<smiles>C1=CO[Al]C=C1</smiles>

$\mathrm{E}$<smiles>C1=CO[AlH][AlH]C=C1</smiles>

$\mathrm{F}$<smiles>O[Al]1(O)C=CO1</smiles>

H<smiles>O[Al](O)O[Al]1(O[Al](O)O)C=CC=C[Al](O[Al](O)O)(O[Al](O)O)O1</smiles>

G<smiles>O[Al]1C=CO[Al](O)O1</smiles><smiles>O[Al]1(O)C=CC=CO1</smiles>

।

Figure 2. Calculated models for the reaction of enolic species on $\mathrm{Ag} / \mathrm{Al}_{2} \mathrm{O}_{3}$ catalyst.

$\left.\mathrm{O}^{-}\right)-\mathrm{M}^{+}$. For reaction $2, \mathrm{C}_{2} \mathrm{H}_{5} \mathrm{OH}$ is first oxidized to $\mathrm{CH}_{3} \mathrm{CHO}$, which then condensates and dehydrogenates to yield $\mathrm{CH}_{3} \mathrm{CH}=$ $\mathrm{CHCHO}$, followed by degradation and isomerization to $\mathrm{CH}_{2}=$ $\mathrm{C}=\mathrm{CHOH}$ compound, and a further reaction of this compound finally leads to the formation of $\left(\mathrm{CH}_{2}=\mathrm{C}=\mathrm{CH}-\mathrm{O}^{-}\right)-\mathrm{M}^{+}$. The mechanism of reaction 3 is similar to that of reaction 2 .

4.2.3. Vibrational Frequency Calculation. Structural optimizations and vibrational frequency calculation for models $\mathrm{A}-\mathrm{J}$ were carried out at B3P86/LANL2DZ. Calculated frequencies are listed in Table 1. Simulant spectra for models A-J are shown in Figures 3-5.

The calculated antisymmetric stretching vibrational modes of the adsorbed enolic species for models A-J are 1645, 1693, 1505, 1599, 1694, 1654, 1597, 1694, 1900, and $1571 \mathrm{~cm}^{-1}$, respectively (Figures 3-5). In comparison with the same experimental frequency of $1633 \mathrm{~cm}^{-1}$, the error is on average about $12 \mathrm{~cm}^{-1}$ for model A, $60 \mathrm{~cm}^{-1}$ for model $\mathrm{B},-128 \mathrm{~cm}^{-1}$ for model $\mathrm{C},-34 \mathrm{~cm}^{-1}$ for model $\mathrm{D}, 61 \mathrm{~cm}^{-1}$ for model $\mathrm{E}, 21$ $\mathrm{cm}^{-1}$ for model $\mathrm{F},-36 \mathrm{~cm}^{-1}$ for model $\mathrm{G}, 61 \mathrm{~cm}^{-1}$ for model $\mathrm{H}, 267 \mathrm{~cm}^{-1}$ for model I, and $-62 \mathrm{~cm}^{-1}$ for model J. The calculated frequencies of model A at $1645 \mathrm{~cm}^{-1}$ with $314 \mathrm{~km} /$ mol intensity and model $\mathrm{F}$ at $1654 \mathrm{~cm}^{-1}$ with $61 \mathrm{~km} / \mathrm{mol}$ intensity in Figures 3 and 4 are relatively good matches of the most intense bands at $1633 \mathrm{~cm}^{-1}$ in the experimental spectrum (Figure 1).

The calculated symmetric stretching vibrational modes of the adsorbed enolic species for the models A-J are 1429, 1446, 1344, 1531, 1438, 1431, 1406, 1449, 1447, and $1406 \mathrm{~cm}^{-1}$, respectively (Figures 3-5). For the same experimental frequency of $1416 \mathrm{~cm}^{-1}$, overestimation of experimental frequency values is about $0.92 \%$ for model $\mathrm{A}, 2.12 \%$ for model $\mathrm{B}, 8.12 \%$ for model D, $1.55 \%$ for model E, $1.06 \%$ for model F, $2.33 \%$ for model $\mathrm{H}$, and $2.18 \%$ for model I; underestimation of experi-
TABLE 1: Calculated Vibrational Frequencies $\left(\mathrm{cm}^{-1}\right)$ at the B3P86/LANL2DZ Level for the Ten Calculated Models

\begin{tabular}{ccccl}
\hline model & $\begin{array}{c}\text { freq } \\
\left(\mathrm{cm}^{-1}\right)\end{array}$ & $\begin{array}{c}\text { intensity } \\
(\mathrm{km} / \mathrm{mol})\end{array}$ & $\begin{array}{c}\text { experiment } \\
\left(\mathrm{cm}^{-1}\right)\end{array}$ & \multicolumn{1}{c}{ vibration mode } \\
\hline A & 1645 & 314 & 1633 & enolic species a-str \\
& 1429 & 67 & 1416 & enolic species a-str \\
& 1328 & 16 & 1336 & C-H def \\
B & 1693 & 246 & 1633 & enolic species a-str \\
& 1446 & 50 & 1416 & enolic species str \\
& 1264 & 320 & 1336 & C-H def \\
C & 1505 & 6 & 1633 & enolic species a-str \\
& 1344 & 28 & 1416 & enolic species str \\
& 1262 & 145 & 1336 & C-H def \\
D & 1599 & 104 & 1633 & enolic species a-str \\
& 1531 & 279 & 1416 & enolic species str \\
& 1370 & 78 & 1336 & C-H def \\
E & 1694 & 127 & 1633 & enolic species a-str \\
& 1438 & 55 & 1416 & enolic species str \\
& 1362 & 86 & 1336 & C-H def \\
F & 1654 & 61 & 1633 & enolic species a-str \\
& 1431 & 20 & 1416 & enolic species str \\
& 1347 & 53 & 1336 & C-H def \\
G & 1597 & 408 & 1633 & enolic species a-str \\
& 1406 & 120 & 1416 & enolic species str \\
& 1138 & 648 & 1336 & C-H def \\
H & 1694 & 275 & 1633 & enolic species a-str \\
& 1449 & 61 & 1416 & enolic species str \\
& 1375 & 87 & 1336 & C-H def \\
I & 1900 & 229 & 1633 & enolic species a-str \\
& 1447 & 17 & 1416 & enolic species str \\
& 1368 & 56 & 1336 & C-H def \\
J & 1571 & 139 & 1633 & enolic species a-str \\
& 1406 & 57 & 1416 & enolic species str \\
& 1377 & 17 & 1336 & C-H def \\
& & & &
\end{tabular}

mental frequency values is about $0.71 \%$ for models $\mathrm{G}$ and $\mathrm{J}$. The symmetric stretching vibrational mode of the adsorbed enolic species of model A calculated at $1429 \mathrm{~cm}^{-1}$ with $68 \mathrm{~km} /$ 

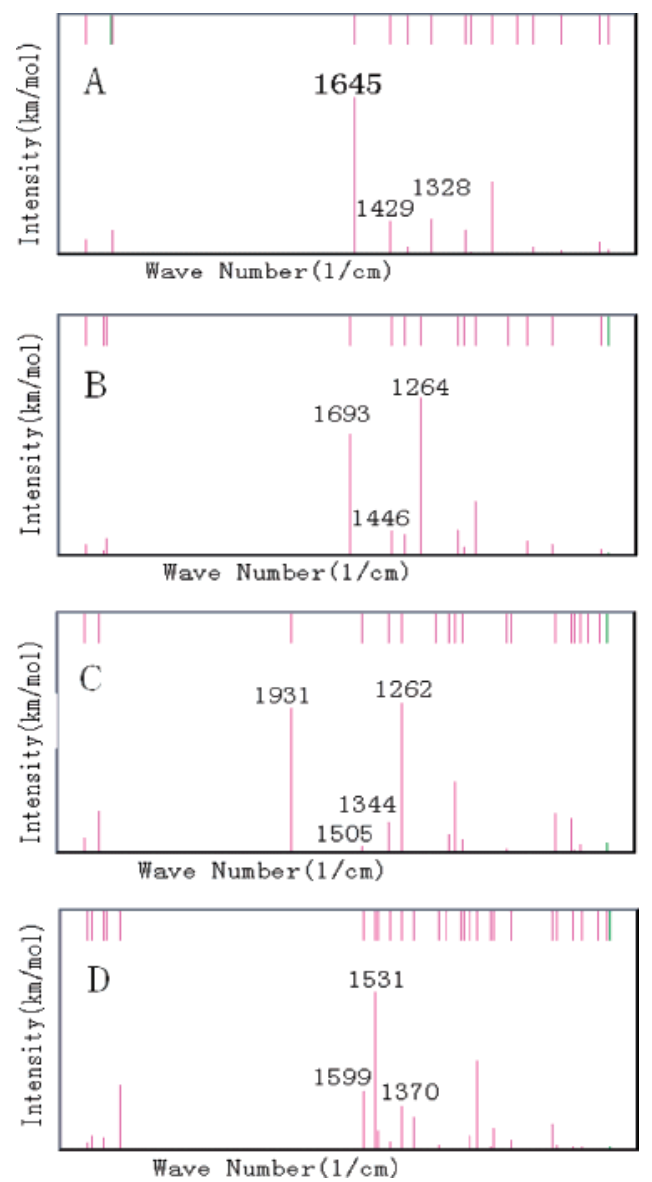

Figure 3. Calculated vibrational IR spectra for the models A, B, C, and D at the DFT-B3P86/LANL2DZ level.
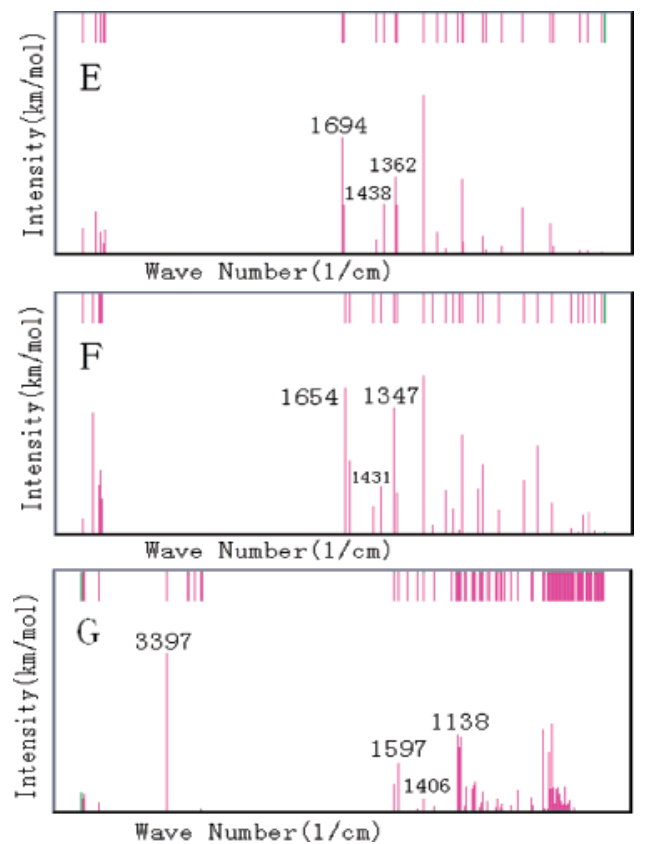

Figure 4. Calculated vibrational IR spectra for the models E, F, and $\mathrm{G}$ at the DFT-B3P86/LANL2DZ level.

mol intensity is only $13 \mathrm{~cm}^{-1}$ higher than the experimental spectrum at $1416 \mathrm{~cm}^{-1}$ with strong absorbance within $0.92 \%$ error. The symmetric stretching vibrational mode of the adsorbed enolic species of models $\mathrm{G}$ and $\mathrm{J}$ calculated at $1406 \mathrm{~cm}^{-1}$ is only $10 \mathrm{~cm}^{-1}$ lower than the experimental spectrum at 1416 $\mathrm{cm}^{-1}$ with strong absorbance within $1.06 \%$ error. The expressed

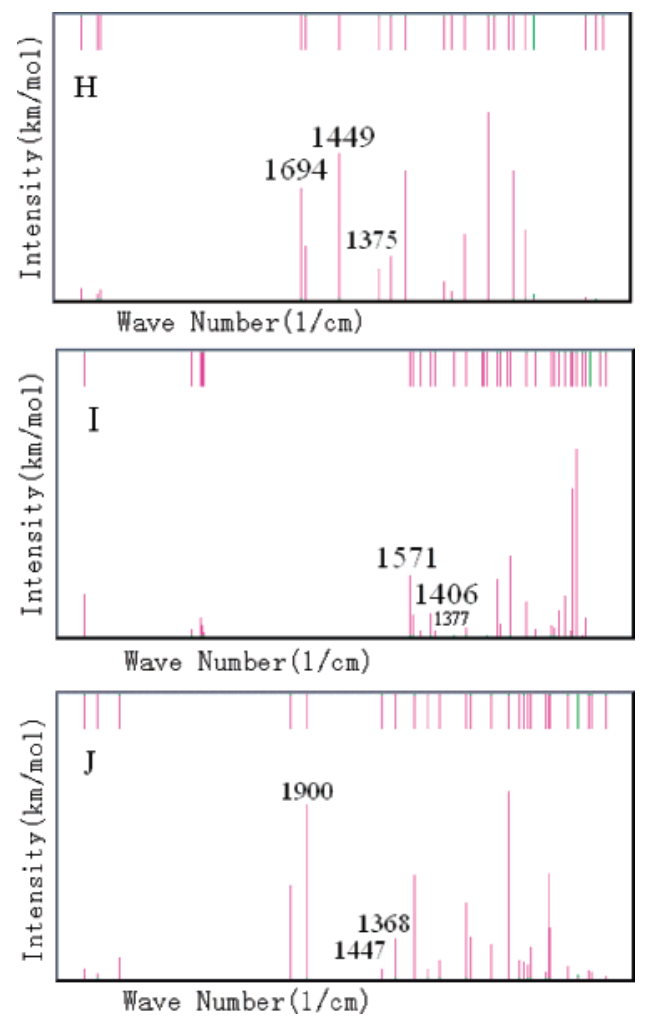

Figure 5. Calculated vibrational IR spectra for the models $\mathrm{H}$, I, and $\mathrm{J}$ at the DFT-B3P86/LANL2DZ level.

frequency at $1429 \mathrm{~cm}^{-1}$ for model $\mathrm{A}$ in Figure 3 and that at $1406 \mathrm{~cm}^{-1}$ for models $\mathrm{G}$ and $\mathrm{J}$ in Figure 4 are relatively good matches of the most intense bands at $1416 \mathrm{~cm}^{-1}$ in the experimental spectrum (Figure 1).

The calculated $\mathrm{C}-\mathrm{H}$ deformation vibrational modes of the adsorbed enolic species for the models $\mathrm{A}-\mathrm{J}$ are 1328, 1264, $1262,1370,1362,1347,1138,1375,1368$, and $1377 \mathrm{~cm}^{-1}$, respectively (Figures 3-5). In comparison with the same experimental frequency of $1336 \mathrm{~cm}^{-1}$, the error is on average about $-8 \mathrm{~cm}^{-1}$ for model $\mathrm{A},-72 \mathrm{~cm}^{-1}$ for model $\mathrm{B},-74 \mathrm{~cm}^{-1}$ for model C, $34 \mathrm{~cm}^{-1}$ for model D, $26 \mathrm{~cm}^{-1}$ for model E, 11 $\mathrm{cm}^{-1}$ for model $\mathrm{F},-198 \mathrm{~cm}^{-1}$ for model $\mathrm{G}, 39 \mathrm{~cm}^{-1}$ for model $\mathrm{H}, 32 \mathrm{~cm}^{-1}$ for model I, and $41 \mathrm{~cm}^{-1}$ for model J. The calculated spectra of model A at $1328 \mathrm{~cm}^{-1}$ with $16 \mathrm{~km} / \mathrm{mol}$ intensity and model $\mathrm{F}$ at $1347 \mathrm{~cm}^{-1}$ with $53 \mathrm{~km} / \mathrm{mol}$ are similar to the experimental spectrum at $1336 \mathrm{~cm}^{-1}$ with strong absorbance. The expressed frequency at $1328 \mathrm{~cm}^{-1}$ for model A in Figure 3 and that at $1347 \mathrm{~cm}^{-1}$ for model $\mathrm{F}$ in Figure 4 are relatively good matches of the most intense bands at $1336 \mathrm{~cm}^{-1}$ in the experimental spectrum (Figure 1).

Comparison with the experimental data shows that the spectra of models A and F simulated by DFT-B3P86 evidently best match the experimental counterparts for the overwhelming majority of the calculated models $\mathrm{A}-\mathrm{J}$ considered in the present study.

4.2.4. Adsorption Energy. The adsorption energies $\left(E_{\mathrm{ads}}\right)$ in the present study are deduced by

$$
\mathrm{E}_{\text {ads }}=E_{\text {cluster/adsorbate }}-E_{\text {cluster }}-E_{\text {adsorbate }}
$$

where $E_{\text {cluster/adsorbate }}$ is the total energy of the adsorbate on the cluster, $E_{\text {cluster }}$ is the total energy of the bare cluster $\left(\mathrm{Ag} / \mathrm{Al}_{2} \mathrm{O}_{3}\right.$ catalyst), and $E_{\text {adsorbate }}$ is the energy of the adsorbate (enolic species).

The calculated $E_{\text {ads }}$ of models A-J are $-180.77,-204.92$, $-158.82,-186.10,-196.43,-184.40,-106.85,-154.81$, 
$-137.35,-157.88 \mathrm{kcal} / \mathrm{mol}$, respectively. The negative $E_{\text {ads }}$ values indicate that the adsorbed state (cluster/adsorbate) is energetically favorable. On the basis of the entire comparison of the $E_{\text {ads }}$ values, it is clear that the order of the energetic stability of the adsorption states of the enolic species on the $\mathrm{Ag} / \mathrm{Al}_{2} \mathrm{O}_{3}$ catalyst surface can be described as model $\mathrm{B}>$ model $\mathrm{E}>\operatorname{model} \mathrm{D}>\operatorname{model} \mathrm{F}>\operatorname{model} \mathrm{A}>\operatorname{model} \mathrm{C}>\operatorname{model} \mathrm{J}>$ model $\mathrm{H}>$ model $\mathrm{I}>\operatorname{model} \mathrm{G}$. We conjecture that models $\mathrm{B}$ and $\mathrm{E}$ are more favorable on thermodynamics, but the formation of those structures is forbidden on dynamics. All models have big $E_{\text {ads }}$ value, therefore, we consider that the enolic species easily formed on the $\mathrm{Ag} / \mathrm{Al}_{2} \mathrm{O}_{3}$ catalyst surface.

\section{Conclusions}

Simulating infrared spectra with the density functional theory (DFT) method can be considered as an advantageous auxiliary tool for the FTIR identification of unambiguous compounds. The calculations show clearly that the calculated IR spectra for models $\mathrm{A}$ and $\mathrm{F}$ are of reasonable similarity to the corresponding experimental one. We conclude that models $\mathrm{A}$ and $\mathrm{F}$ are the reasonable models for the enolic species adsorption on the $\mathrm{Ag}$ / $\mathrm{Al}_{2} \mathrm{O}_{3}$ surface. The result of the adsorption energy shows that enolic species easily adsorbed on the $\mathrm{Ag} / \mathrm{Al}_{2} \mathrm{O}_{3}$ catalyst surface.

Acknowledgment. This work was financially supported by the Innovation Program of the Chinese Academy of Sciences (KZCX3-SW-430) and the State Hi-tech Research and Development Project of the Ministry of Science and Technology, Peoples Republic of China (Grant 2003AA643010).

\section{References and Notes}

(1) Miyadera, T.; Yoshida, K. Chem. Lett. 1993, 1483.
(2) Sumiya, S.; He, H.; Abe, A.; Takezawa, N.; Yoshida, K. J. Chem. Soc., Faraday Trans. 1998, 94, 2217.

(3) Yu, Y.; He, H.; Feng Q. J. Phys. Chem. B 2003, 107, 13090.

(4) Burch, R.; Breen, J. P.; Meunier, F. C. Appl. Catal. B 2002, 39, 283.

(5) Meunier, F. C.; Zuzaniuk, V.; Breen, J. P.; Olsson, M.; Ross, R. H. Catal. Today 2000, 59, 287-304

(6) Yu, Y.; He, H.; Feng, Q.; Gao, H.; Yang, X. Appl. Catal. B 2004, $49,159$.

(7) Standard IR Spectra, Sadtler Research Labs. 4029.

(8) Rodler, M.; Blom, C. E.; Bauder, A. J. Am. Chem. Soc. 1984, 106 ,

(9) Koga, Y.; Nakanaga, T.; Sugawara, K.; Watanabe, A.; Sugie, M.; Takeo, H.; Kondo, S.; Matsumura, C. J. Mol. Spectrosc. 1991, 145, 315.

(10) Duck-Lae, J.; Merer, A. J.; Clouthier, D. J. J. Mol. Spectrosc. 1999, $197,68$.

(11) Van Santen, R. A.; Neurock, M. Catal. Rev. Sci. Eng. 1995, 37, 557.

(12) Fahmi, A.; Van Santen, R. A. J. Phys. Chem. 1996, 100, 5676.

(13) Siegbahn, P. E. M. Adv. Chem. Phys. 1996, 93, 333.

(14) Van Santen, R. A. In Chemisorption and Reactivity on Supported Clusters and Thin films; NATO ASI Series E: Applied Sciences; Lambert, R. M., Pacchioni, B., Eds.; Kluwer: Dordrecht, The Netherlands, 1997; Vol. 331, p 371.

(15) Paul, J. F.; Sautet, P. Stud. Surf. Sci. Catal. 1996, 101, 1253.

(16) Yokoyama, C.; Misono, M. J. Catal. 1994, 150, 9.

(17) Tanaka, T.; Okuhara, T.; Misono, M. Appl. Catal. B 1994, B4, L1.

(18) Bethke, K. A.; Li, C.; Kung, M. C.; Yang, B.; Kung, H. H. Catal. Lett. 1995, 31, 287.

(19) Shimizu, K.; Shibata, J.; Yoshida, H.; Satsuma, A.; Hattori, T. Appl. Catal. B 2001, 30, 151.

(20) Meunier, F. C.; Zuzaniuk, V.; Breen, J. P.; Olsson, M.; Ross, J. R. H. Catal. Today 2000, 59, 287.

(21) Meunier, F. C.; Breen, J. P.; Zuzaniuk, V ; Olsson, M.; Ross, J. R. H. J. Catal. 1999, 187, 493.

(22) Shimizu, K.; Satsuma, A.; Hattori, T. Appl. Catal. B 2000, 25, 239.

(23) Rajh, T.; Chen, L. X.; Lukas, K.; Liu, T.; Thurnauer, M. C.; Tiede, D. M. J. Phys. Chem. B 2002, 106, 10543.

(24) Yu, Y.; Gao, H.; He, H. Catal. Today 2004, 93-95, 805. 